\title{
Accelerating Diffusion Innovation Using Celebrities as Opinion Leaders for Millennials: HPV Vaccines in Indonesia
}

\author{
JANETTE MARIA PINARIYA \\ ANDRE IKHSANO \\ ALDILA MAHARANI SUTJIPTO \\ LSPR Communication \& Business Institute, Jakarta
}

\begin{abstract}
Indonesia has become the country with the second-highest number of cervical cancer patients. It is the only type of cancer that could be prevented, but the public's understanding is still very low. The urgency of this issue especially applied for the millennial generation. This study discusses the campaigns in the health sector conducted by Indonesia Cervical Cancer Prevention Coalition as an effort to introduce HPV vaccination as primary prevention of cervical cancer, where one of the main strategies used is by maximizing the role of celebrities as opinion leaders. This paper discusses how cervical cancer preventive measures are often seen as sensitive, frightening, and embarrassing by the millennial generation in Indonesia. Aims to obtain information about the use of celebrity opinion leaders as one of the KICKS communication strategies, obstacles faced and how to deal with them. The authors use a qualitative approach, with primary data obtained through interviews with seven informants. By using diffusion of innovation theory approach from Everett M. Rogers, which focuses on the role of opinion leaders, the results of this study show that what is done and said by opinion leaders regarding an innovation can be an important consideration for millennials. Where similarities that celebrities had as a part of the social system help making the message more relevant, memorable, reliable and trustworthy. However, it could not be denied that the use of celebrities as opinion leaders has its advantages and disadvantages, and besides that interpersonal communication is still needed.
\end{abstract}

Keywords: Health communication, HPV vaccines, opinion leader, multi-step flow theory, diffusion of innovation.

\section{INTRODUCTION}

Health communication is a powerful and generally complicated field because it requires an in-depth understanding of existing diseases and is often misunderstood because it uses terms and words that are complex and rarely known (Parrott, 2009). However, on the other hand, health communication has an important and crucial role, since it can make people obtain, process, and understand basic health information and services needed to make appropriate health decisions (Selden, Zorn, Ratzan \& Parker, 2000). Health communication also has the role to increase individual awareness about health issues, causes, problems, impacts, prevention, and treatment because most diseases today are caused by a lack of health insight and access, especially for the millennial generation, where despite their need for health services, millennials use it less often than older generations did (Han et al., 2015). This happens because they are generally in a healthy condition or assume that they are, so they do not access the health services as much as the adults.

One example that is happening now is cervical cancer detection in Indonesia. Cervical cancer is deadly cancer that attacks the cervix, and based on the data from the Indonesian Ministry of Health has become cancer with the highest prevalence rate that attacks Indonesia women (Sukmawati, 2018). It is estimated that every year there are 32,469 Indonesian 
women diagnosed with cervical cancer and 18,279 dies from this disease, where this disease ranks second among Indonesian women (Setiawan et al., 2016). While based on available data, Indonesia is the second-highest number of cervical cancer patients after China (Global Cancer Observatory, 2018). World Health Organisation (WHO) estimates that deaths from cervical cancer will increase by almost $50 \%$ by 2030 (Ghebreyesus, 2018).

Besides this worrisome situation, cervical cancer has its uniqueness, as it is the only type of cancer that could be prevented and if detected earlier could be treated by up to 100 per cent (Budiwati, 2012). The HPV vaccine is primary prevention of cervical cancer which was first licensed in 2006 and WHO recommends this vaccine to be included in the national immunisation program. It has also been approved by the Food and Drug Administration (FDA) and recommended by the Center for Disease Control and Prevention (CDC) with girls aged 914 years old as its primary target group because at this age most children are not sexually active yet (Centers for Disease Control and Prevention, 2016).

However, it is regrettable that the presence of HPV vaccine that could be a solution to prevent cervical cancer has not been maximally utilised in Indonesia. Ayuningtyas and Sutrisnawati (2018), Anwar et al. (2018), Nurhasanah and Afriyanti (2017), Titisari and Setyarini (2017), Onuki et al. (2020), Sutjipto and Pinariya (2019), Handayani et al. (2017), with Spagnoletti et al. (2019) have found that Indonesian's public awareness regarding this issue was still low. This includes millennial generations that are defined by Berkup (2014) as individuals who were born between 1980 and early 2000. Many of them who do not know and understand what cervical cancer is and the importance of HPV vaccination. However, it is essential to deliver health messages for millennials, as the development of their health literacy skills may support informed health-seeking lifestyles, they are part of the future independent health care system users, and few studies stated that they have low health literacy (Ghaddar et al., 2012)

During this condition, the only non-profit organisation that is most focused and active in introducing cervical cancer and the importance of HPV vaccination in Indonesia is Koalisi Indonesia Cegah Kanker Serviks (Indonesia Cervical Cancer Prevention Coalition). KICKS is an organisation that was established on April 2017 by several nonprofit organisations, both from the medical (Yayasan Kanker Indonesia, Indonesia Working Group HPV, Cancer Information \& Support Center, Yayasan Kesehatan Perempuan, Himpunan Onkologi Ginekologi) and nonmedical community (Fatayat NU, Kalyanamitra, Yayasan Puteri Indonesia) which work together towards effective prevention of cervical cancer in Indonesia.

KICKS public relations through Cegah Kanker Serviks (Cervical Cancer Prevention) campaign formed various strategies to introduce HPV vaccination as a form of innovation, by carrying out various activities, both online and offline (Koalisi Indonesia Cegah Kanker Serviks, n.d). Various communication activities can be done to introduce an innovation so it will be adopted by a group of people, and one of the main strategies used is by maximising the role of opinion leaders. This is in line with KICKS strategy, where they have several opinion leaders who are actively involved, all of them have a primary role as a communicator and connecting bridge in introducing HPV vaccinations. One from many types of opinion leaders who are considered interesting is the use of celebrities as 'Duta kanker serviks' (the ambassadors of cervical cancer). Opinion leader was defined by Rogers (2003) as an individual who leads in influencing others' opinions about innovations, they are individuals or groups who provide information as well as suggestions related to the innovation to members of the social system. 
What is done and said by opinion leaders related to innovation can be an important consideration for individuals or other recipient units of the innovation. Where lastly, the behaviour of opinion leaders is important in determining the rate of adoption of an innovation in a social system.

Based on previous research, state of the art, Li and Du (2011) state that, in general, programs that use opinion leaders are more effective than those that do not. This happened because they are normally more interconnected, have a higher status, education, and social standing. Hoffman et al. (2017) add that the use of celebrity as opinion leaders could also have a tremendous influence on society's knowledge, attitudes, and decisions including those that affect people's health. Hoffman and Tan (2015) also state similar affirmations in their research, where they explain that celebrities frequently give medical advice and people often follow it. Celebrity endorsements can generate large publicity for health campaigns, and the appearance of new media and technology improvement has made celebrity advice spread far wider and more rapidly than ever before, making its influence increasingly pervasive and powerful. They are either doing it motivated by good intentions or financial compensation.

\begin{abstract}
A 2009 survey of 1,552 Americans found that $24 \%$ of parents place 'some trust' in vaccine safety information given by celebrities.... Celebrities can thus act as powerful public health tools, agents who disseminate and encourage health behaviours of proven benefit. However, their influence becomes deeply troubling when their medical advice is uninformed and possibly dangerous (Hoffman \& Tan, 2015, p. 2).
\end{abstract}

In line with that, Yoo (2015) describe that celebrities may function as representative exemplars because people tend to take a phenomenon that is experienced by celebrities as something more serious. The popularity that celebrities had makes the message becoming more relevant, memorable, reliable and trustworthy. Cram et al. (2003) also add by illustrating about how the use of celebrity spokespersons to influence public behaviour is common outside the public health arena, where research has demonstrated that celebrity disclosure of their illnesses can increase public interest in the specific disease and can change the public's behaviour. However, no study has specifically addressed the impact of a health celebrity spokesperson on the public's participation in preventive measures such as cancer screening programs in Indonesia yet. So based on these, this study hopes to discuss further how celebrity as an opinion leader could affect health messages delivery.

This is in line with the introduction of the HPV vaccine as a preventive medium for various diseases, especially cervical cancer, which is often seen as sensitive, frightening, and embarrassing by millennial generations in Indonesia, where theoretically, celebrity advocates can help reduce the stigma and fear associated with examining and prevention of disease so that it can help increase awareness and participation to save more lives. So based on this statement the author is interested in looking further into the introduction of HPV vaccination strategies used by KICKS by using a celebrity opinion leader as one of the communication strategies, obstacles faced and how to deal with it. This study uses diffusion of innovation theory approach from Everett M. Rogers (2003), focusing on the role of opinion leaders in the diffusion of innovations where the concept of opinion leader here appears as one of the elements in the social system that influences the spread of innovation. The approach using this theory is considered under the existing discussion because it could give in-depth 
information about how HPV vaccination as innovation is communicated to be adopted by members of the social system by using celebrity opinion leaders as one of the strategies. This is also based on the idea that the successful application of an idea will depend on the communication process attempted. This study is expected to provide information regarding the role of celebrity opinion leaders in introducing innovations in the health sector to Indonesians as an effort to prevent disease.

\section{LITERATURE REVIEW}

Diffusion of Innovation theory is one of the theories that was put forward by Everett $\mathrm{M}$. Rogers in 1962. Although this theory is already quite old, its application is still valid and being used until now, given that as time evolved, various innovations have emerged in various fields, including in the health industry. Innovation is defined by Rogers (2003) as "an idea, practice, or object that is perceived as new by an individual or other unit of adoption" (p. 73). The novelty referred to here is seen based on individual reactions. If an idea seems something new to the individual, then it could be categorised as innovation while diffusion is defined as ".... the process by which an innovation is communicated through certain channels over time among the members of a social system" (p. 61). Diffusion could also be seen as a special type of communication where the message involves the introduction of a new idea (Rizal, 2012). The diffusion of innovation does not just happen. There are main elements which will affect one another, and determine whether innovation can be accepted by the adoption recipient in the end. One of the elements is the social system that further discusses the role of opinion leaders. A social system is defined as "a set of interrelated units that are engaged in joint problem solving to accomplish a common goal" (Rogers, 2003, p. 95). The members of a social system may be individuals, informal groups, organisations, and/or subsystems, where all members cooperate at least to the extent of seeking to solve a common problem to reach a mutual goal. The social system constitutes a boundary within which an innovation diffuses. Here we shall deal with many topics, and one of them is the roles of opinion leaders.

There are members of the system who function in the role of opinion leader, where generally they provide information and advice about innovations to the members of the social system. Opinion leaders are defined by Rogers (2003) as individuals who lead in influencing the opinions of others related to an innovation, where the behaviour of opinion leaders is important in determining the level of adoption of an innovation in the social system. The immense interpersonal network of opinion leaders enables them to become social models whose innovative behaviour will be imitated by many people. In general, when opinion leaders are compared with their followers, it was found that they are more exposed to all forms of external communication, more cosmopolite, have somewhat higher social status, and more innovative. But one of the most striking characteristics of opinion leaders is their unique and influential position in their system's communication structure, they are at the centre of interpersonal communication networks (Rogers, 2003).

To discuss further the role of celebrity as opinion leaders, the author also used the multi-step flow theory that was emerged as an extension of the two-step flow theory delivered by Katz \& Lazarsfeld (Ognyanova, 2017). This theory state that based on studies conducted, mass media does bring changes to people but the effect is rather small, where in contrast, in making decisions, people seem to be far more influenced by direct communication with other people (Lazarsfeld et al., 1944). Katz and Lazarsfeld (1955) found that "opinion leaders acted as influential modifiers of information that was distributed through mass media sources" (in Stansberry, 2012, p. 17). Opinion leaders have a certain 
influence on society through interpersonal communication where the more frequent and effective personal contact made, the more they could influence others' perceptions, motivations, attitudes and actions (Emma et al., 2017).

Unlike the two-step flow, multi-step flow theory explains that communication patterns that occur between opinion leaders and the community can be formed from various directions.

This allowed the inclusion of other optional directions of flow, such as horizontal (between leaders, between followers) and vertical (leaders to followers, active to inactive); direct (linking two actors directly) and indirect (linking actors through a third party or a chain of intermediaries); and downward (leaders to followers, media to the public) and upward (leaders to media, followers to influentials, marginals to centrals) (Weimann, 2017, p. 5).

Besides, this theory also describes the audience as active participants where they can provide feedback to respond to the messages received.

Finally, as the complement of the concepts and theories that will be used as a reference in the discussion section, the authors also use health communication concepts, that according to Thomas (in Wilujeng \& Handaka, 2017) includes all learning and the use of communication strategies to provide information and influence the knowledge, attitudes, and behaviours of the community regarding health. Health communication can contribute to all aspects regarding disease management and health promotion, including increase individual awareness about health issues, problems, risks, and solutions (Rahmadiana, 2012). Health communication is generally complicated because it requires a deep understanding regarding the disease and is often misunderstood because it uses terms and words that are complex and rarely known, in other words, complex words are words or terms that are not used in daily conversation, even when someone talks about health (Parrott, 2009). It has an important role in raising individual awareness because most diseases today are caused by shortness of health insight and access. It operates within a very complex environment which encourages and supports people to adopt and sustain healthy behaviours. Whereas, for example, the author talks about HPV vaccines that have become one of the medical and scientific successes of recent times that have been proven could prevent cervical cancer and other diseases causes by HPV, yet as for most other health-related issues, changing public minds has required a worldwide multidisciplinary effort. Health communication then has played a fundamental role to introduce innovation in the health industry, where it "is an integral part of everyday life as well as various interventions for health and social change" (Schiavo, 2014, p. xxviii).

\section{METHODOLOGY}

This study tries to discern how a celebrity as an opinion leader could affect health messages delivery to millennials by using diffusion of innovation theory approach from Everett $\mathrm{M}$. Rogers (2003) focusing on the role of opinion leaders, supported by multi-step flow theory and health communication concept. To answer the problem formulation, the author used a qualitative method, with a case study format, which focuses on a particular unit of a various phenomenon, namely the use of celebrity as an opinion leader by KICKS in introducing HPV vaccination. This method is considered suitable to be able to provide an overview of the 
concepts to provide in-depth information about research topics.

Data collection techniques were carried out by used semi-structured interviews with seven informants, which were considered be able to represent the desired information and fulfil the research purpose, including Prilly Latuconsina as the ambassador of cervical cancer (Duta Kanker Serviks), Sondang Butar Butar as KICKS public relations, Novi Henriatika as KICKS public relations, Listyowati as KICKS member, Dr. Ardiansjah Dara Sjahruddin as an obstetrician, Levina Masli as one of Indonesia's millennials, and Citra Pulandi Utomo as one of Indonesia's millennials.

To test the validity of the data, source triangulation techniques are used, by comparing the data obtained through three different points of view, which is KICKS party as communicators, Indonesia millennials representatives as receivers, and health experts as the third parties. For data analysis techniques the authors use the core elements of qualitative data analysis that consist of "coding the data (reducing the data into meaningful segments and assigning names for the segments, combining the codes into broader categories or themes, and displaying and making comparisons in the data graphs, tables, and charts" (Creswell \& Poth, 2018, p. 251).

\section{RESULTS AND DISCUSSION}

Koalisi Indonesia Cegah Kanker Serviks (Indonesia Cervical Cancer Prevention Coalition) is the only nonprofit organisation that is most focused and active in introducing HPV vaccination as cervical cancer prevention in Indonesia. Because this vaccine is not included in the national immunisation program yet, various efforts have been made to increase public knowledge and encourage the government. Among the various strategies carried out in the form of CegahKankerServiks campaign by KICKS, one tactic that is considered interesting and acts as a major weapon is the use of celebrities as opinion leaders. According to Rogers (2003), opinion leaders are individuals or groups who provide information as well as suggestions related to innovation to members of the social system. They are an individual or group of people that have the power to influence others. Meanwhile, the use of celebrities as opinion leaders often happens where Valente (2008) stated that they could also be effective at selling health messages, either intentionally or unintentionally. The use of a celebrity as an opinion leader is considered suitable since based on Kelly (2004) research,

..... new behavioural trends can become established when enough natural, popular, well-liked opinion leaders who are themselves members of the target population are seen by others to have adopted a behavioural innovation, endorse it, and when the modelled behaviour change is perceived by others to be good, fashionable, and beneficial (p. 142).

These celebrities are dubbed as Duta Kanker Serviks (Servical Cancer Ambassadors), who actively voice and provide education to Indonesian, both online, and offline. These cervical cancer ambassadors include Wulan Guritno, Dewi Sandra, Prilly Latuconsina, Syifa Hadju, Melly Goeslaw, Dewi Sandra, Bunga Jelitha, Ruben Onsu, and Sarwendah. The selection of these celebrities by KICKS is based on a variety of considerations, as explained by N.Henriatika as KICKS public relations as follows: 
... we choose them based on the reflection of a woman in every segment. For example, vaccination is especially important for young people, so we use Prilly and Syifa Hadju to attract millennials who are still in college, school or first jobbers. As for people who are already married, we chose Sarwendah and Ruben Onsu as the spokespersons, and then there is Wulan Guritno, Dewi Sandra, Melly Goeslaw, and many more that fit in and are suitable to represent and help spread the messages ( $N$. Henriatika, personal communication, 13 February 2019).

In this activity, to increase the effectiveness of health messages delivery towards millennial generations, celebrity opinion leaders actively participate in many activities, both online and offline. The use of the right strategy here is really important, because health information, when presented effectively could improve and reinforce the satisfactory outcomes of the preventive behaviour program (Arya, Mohd. Azul \& Mohd. Nor Shahizan, 2019). Regarding online activities, the use of celebrity opinion leaders in new media is considered important and has a big influence in the digital era towards millennials. This is in line with Eng May, Edwin and Teh's (2016) research that explains, another reason that has made health literacy towards millennials quite challenging is due to the behaviour of youth that change according to global trends. It is not easy to understand them and deliver the right message to them at the right time and place. So, to face this KICKS actively participated in a variety of online activities. To increase public awareness and understanding of cervical cancer, KICKS developed a website that became an information centre for all related activities carried out by them. To expand the dissemination of information about cervical cancer to the public, KICKS also made accounts on several social media where through this type of media, people can interact directly, wherever and whenever. Here KICKS uses the hashtag (\#CegahKankerServiks), which is expected to help the message go viral and provide easiness for users to access the information. Some of the activities that are carried out by KICKS via online are daily posts regarding various facts about cervical cancer, offline Activities Review, online competitions, petitions, and one of the most interesting strategies used was an online clinic. 

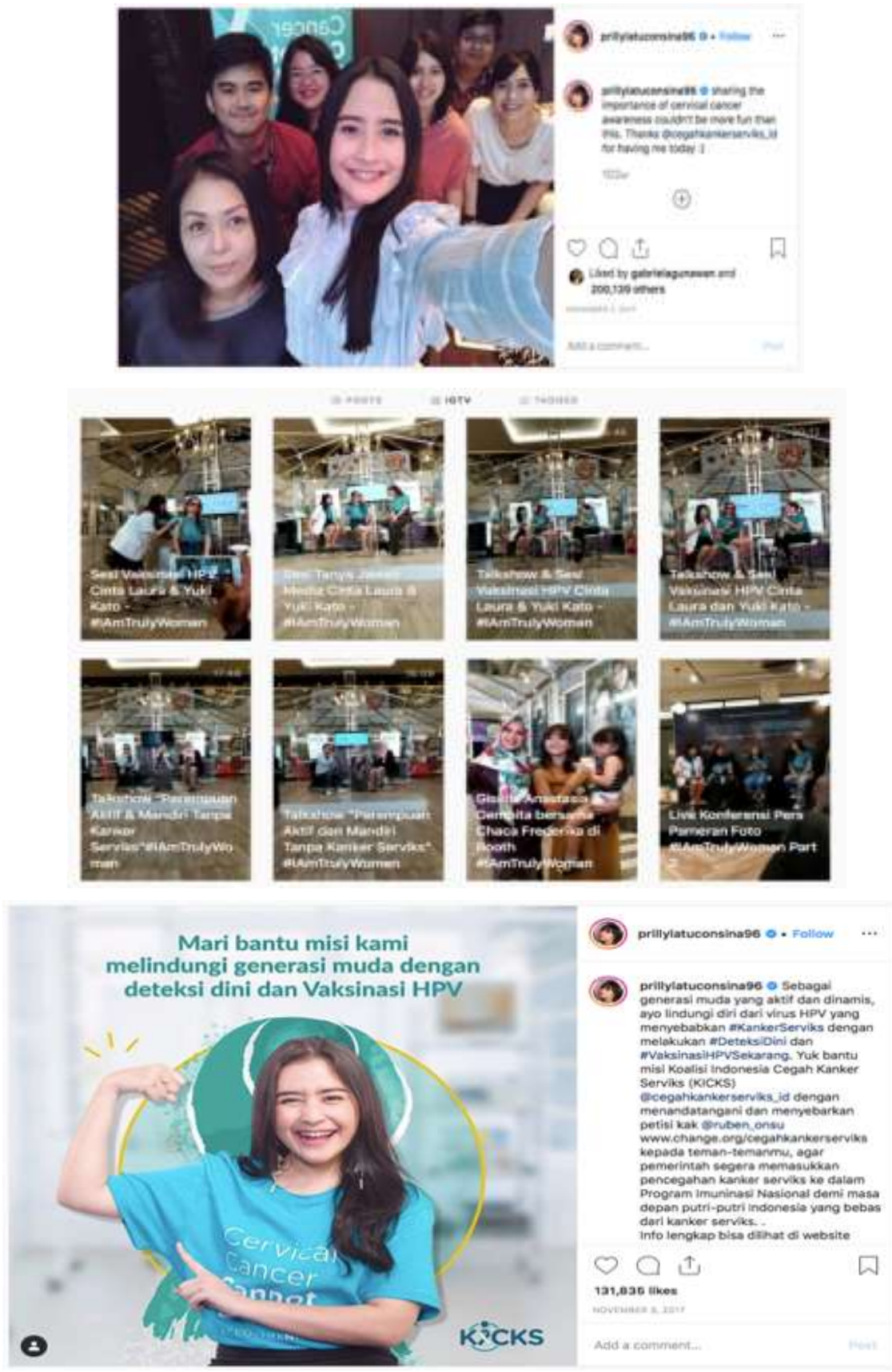

Picture 1: Koalisi Indonesia Cegah Kanker Serviks \& Prilly Latuconsina Instagram

In the online clinic, the cervical cancer ambassadors with experts go live on Instagram and Facebook to discuss related topics. KICKS Public Relations (personal communication, 13 February 2019) explained that this activity is considered quite effective as it makes it easier for people, especially millennials to get an education because they can see the counselling session wherever they are and whenever they want to as long as they have an account. In addition, the public can also provide questions and comments directly on the Instagram live feature. Besides that, through new media, the ambassadors are also required to actively create engagement, either by replying to comments, DM, post activities related to the HPV vaccine, and so on. According to SB Butar (personal communication, 13 February 2019), the use of new media is considered to be the most effective way because most millennials today feel afraid and ashamed to have an examination by a gynaecologist, so through this, they 
could get help and ask questions with much more ease. Until 16 March 2019, KICKS already had around $29 \mathrm{~K}$ followers on Instagram. In addition, based on data obtained by the author, from August 2017 to May 2018 there were approximately 3,533,701 interactions related to KICKS and the introduction of HPV vaccination activities on Instagram.

For offline activities, cervical cancer ambassadors actively participate in many kinds of counselling and education conducted in various locations, such as hospitals, corporate, public areas, schools, and many more. The selection of ambassadors will also be adjusted to existing community groups, and as explained by KICKS PR before, as for millennials, KICKS use Prilly Latuconsina and Syifa Hadju who are one of the millennial generations. In addition, Duta Kanker Serviks also conduct representative trials by conducting HPV vaccinations in front of the public and the media, and this is in line with Rogers (2003) explanation that state trials conducted by known people and opinion leaders will be enough as a kind of representative trial to convince individuals of an innovation. Here Magill and Rogers (in Rogers, 2003) add that agents of change can often accelerate the process of innovation for individuals by demonstrating new ideas in the social system, these activities are proven to have an effective impact, especially if the demonstrator is an opinion leader. KICKS Public Relations explained that the use of celebrities in delivering health messages is a strategy that has a significant impact, especially because they could generate lots of publicity for health campaigns by their visibility, newsworthiness, and public interest. Their presence meant KICKS activities received more attention from the public, as well as the media. One example is in 2018, KICKS managed to get approximately 400 media reports, both in the form of print, broadcast and online media in 11 months, with the majority of positive reporting.
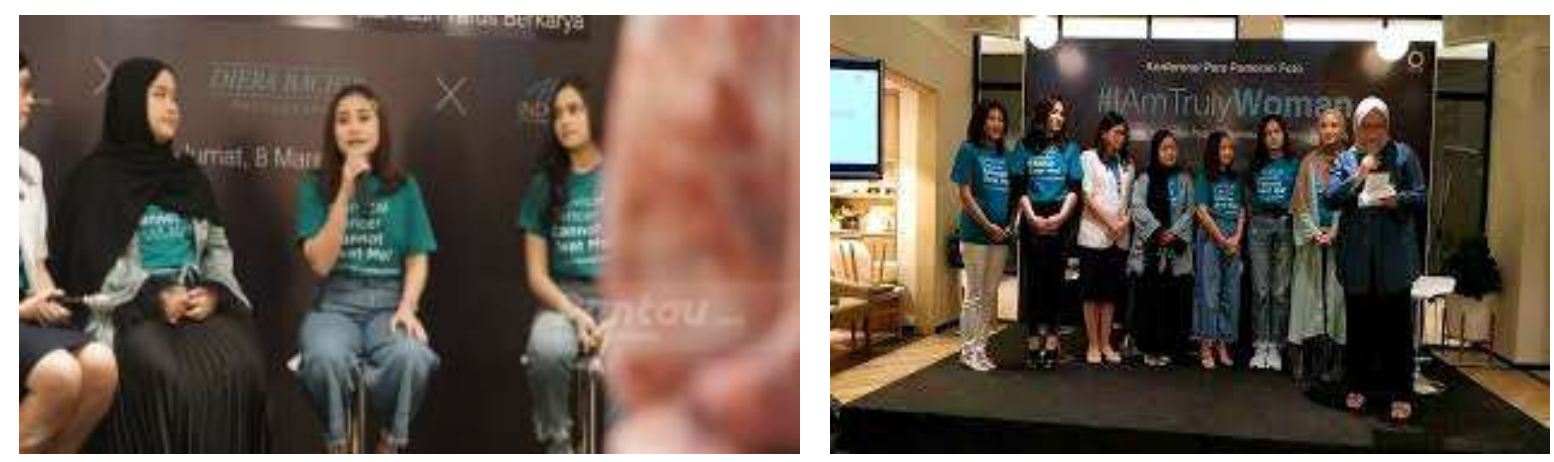

Picture 2: Koalisi Indonesia Cegah Kanker Serviks (n.d.) \& Rifeni (2019)

The use of an opinion leader to deliver health messages has been discussed by many experts, one of them was multi-step flow theory that discusses how mass media does bring changes in people but the effect is rather small, where in contrast, in making decisions people seem to be far more influenced by direct communication with other people (Lazarsfeld et al., 1944, p. 151). Opinion leaders have a certain influence on society through interpersonal communication where the more frequent and effective personal contact is made, the more they could influence others' perceptions, motivations, attitudes and actions (Emma et al., 2017). This statement is somehow proven in HPV vaccination introduction activities, where Listyowati as one of KICKS members and A. D. Sjahruddin as Obgyn, explains that the role of mass media and face to face communication in KICKS activities support each other, but despite their weaknesses and strengths, face to face communication still becomes a necessity in introducing HPV vaccination in Indonesia, including towards millennial generation. 
.... nowadays the majority of people are using social media, but we also can't forget the fact that not everyone had access to it, not everyone uses social media ... I take myself as an example .... so face to face may indeed be more ineffective because even though the cost is higher, it takes more energy, etc, on the other side, it is also still, though conventional, but it is still needed for certain groups of people (Listyowati, personal communication, 12 February 2019).

If I look at it from my experience, it's still more effective when we give seminars because from the face to face communication we could start the explanation slowly and structurize. But indeed I feel that all methods must be tried, that's why primary prevention of cervical cancer is one vaccination, two education. Nowadays education is not just about face to face communication, because we want to reach millions of people, so want it or not we need to maximize the use of technology as well (A. Dara Sjahruddin, personal communication, 21 February 2019).

Besides, Rogers (2003) also states that opinion leaders have several characteristics; they are more exposed to all forms of external communication, more cosmopolite, have somewhat higher social status, and are more innovative. But one of the most striking characteristics of opinion leaders is their unique and influential position in their system's communication structure, where they are at the centre of interpersonal communication networks. In line with this explanation, the use of celebrities as opinion leaders in introducing the HPV vaccine in Indonesia is considered suitable and effective because they generally already meet these characteristics.

Also, the use of celebrity as an opinion leader by KICKS is also considered relevant because of the Indonesia culture that upholds collective (Kuswardani, 2012) as well as paternalism culture (Butar, 2018). In this culture, leaders or people that had high status are placed as the most dominant party and give big influence on the community. The social framework is considered as something strong where an individual is expected to follow the values that were applied in society. What makes it interesting is how people with this culture will tend to be easier to get influenced by others, in this case, opinion leaders (Kau \& Jung, 2004), including in the process of forming opinions, attitudes, and so on in various sectors.

In the context of the HPV vaccination introduction by KICKS, opinion leaders have the main role as communicators and connecting bridge, where they actively attend various education programs conducted both online and offline. However, using celebrities as opinion leaders certainly has its advantages and disadvantages. Related to its advantages Valente (2008) explains that

Using celebrities to promote behaviour change has many advantages. They are highly visible and have acted as opinion leaders within society. Celebrities are also accustomed to being in the spotlight and thus don't have to be trained to speak in public or how to cope with added attention. Celebrities often enjoy taking on causes that are important to them to enhance their image and further solidify their celebrity status (p. 85). 
This advantage was also felt by KICKS public relations, who explains that the role of cervical cancer ambassadors is considered important in helping spread the message, S. B. Butar gave the following statement

So after KICKS launched its next step coalition, we launched our assets, which was social media and also the ambassadors. Why did we do that? Because first, the ambassadors had a lot of followers, so it becomes one of the main strategies to deliver a message to create higher awareness. Because before that people also don't know what KICKS is. So they become the extension of our hands, help us mass our messages (personal communication, 13 February 2019).

It could be seen that what is done and said by opinion leaders regarding an innovation can be an important consideration for millennials. Besides that, the use of celebrities as opinion leaders can also help the process of receiving messages because there are similarities between them and millennials as the members of the social system. So the role of opinion leaders in introducing innovation to millennials is considered in helping the ongoing diffusion of innovation. The role of cervical cancer ambassadors is considered important in helping to spread the message to millennials. This is explained by S. B. Butar as follows

So after KICKS launched, we launched our assets, which was social media and also the ambassadors. Why did we do that? Because first, the ambassadors had a lot of followers, so it became our way to deliver the message, to create a higher awareness. So they are the extension of our hands and helping us in mass our messages (personal communication, 13 February 2019).

However, the use of celebrities as opinion leaders also has disadvantages, which is

.... celebrity can also solicit intense public scrutiny, and if the personal behaviour of a celebrity contradicts the health message he or she is endorsing, the effectiveness of that message decreases (Erdogan, Baker \& Tagg, 2001). Thus, celebrities often need to be educated about their responsibilities as a health opinion leader. They also need to be educated about the health behaviour or message they are supporting, because they are going to be spokespersons, so they need to be able to discuss the topic intelligently. Also, if they are being compensated or in any way identified with a sponsoring agency, there may be contractual agreements on the limitations put on contradictory personal behaviour. Because of these restrictions, it may be difficult as well as costly to recruit celebrities as health opinion leaders (in Valente, 2008, p. 885). 
Related to this, KICKS public relations does a few things to maintain positive perceptions related to HPV vaccination, especially in Indonesia where issues regarding health reproductive remain sensitive, especially to younger generations, due to conflicts between the values of Indonesian traditions and Western globalization that are considered to emerge along with health education reproduction (Benita, 2012). These strategies include conducting rigorous selection and assistance. This was explained by P. Latuconsina as one of Duta Kanker Serviks (personal communication, 29 August 2019), that are specifically chosen by KICKS to represent millennial generations, she stated that before selecting an ambassador, KICKS public relations had several criteria that needed to be fulfilled to represent this role, including not smoking, having a healthy lifestyle, regular exercise, eating healthy food, and not changing partners often.

In addition, KICKS also chooses endorsers who have a strong digital influence, and do not only have many followers but also engagement, such as regularly replying to comments and direct messages. Besides that, personal experience is also a criteria that must be owned and related to this P. Latuconsina (personal communication, 29 August 2019) explained that two of his family died due to cervical cancer. After going through the selection process, KICKS public relations will continue to conduct training related to cervical cancer, HPV vaccination, and health communication strategies, which all were delivered by experts. In addition, after going through the process, in delivering their messages they are also always accompanied by doctors, both when conducting education online and offline. Regarding the strategy carried out by cervical cancer ambassadors to convince the community, P. Latuconsina (personal communication, 29 August 2019) explained that,

The most effective strategy, in my opinion, is by giving examples. Because people will see whether the ambassadors are doing it or not. So I gave an example and socialise the info that I was already vaccinated, my family also were vaccinated, and I also gave information to my closest circle first, that we have to do the vaccinations ... there are some other strategies that we've done as well, such as online clinics, so I was live on Instagram with a doctor. We created it as friendly as possible, so people who asked also did not feel embarrassed, shy, etc. If anyone wants to ask they just need to leave a comment and we will answer it live. We also give information regarding which hospital provides the vaccine at a cheaper price, we also sell bracelets where later on the money would be donated to people who were struggling with cervical cancer and many more.

So based on this explanation, it could be seen that the use of celebrities as opinion leaders in introducing HPV vaccinations to Indonesia's millennials, contributes to increasing message delivery effectiveness, which could further accelerate the rate of diffusion. Although there are many advantages in using them as opinion leaders, more consideration and planning is needed, starting from conducting a rigorous selection process during the recruitment stage, to creating supervising programs when they have already become an ambassador, to ensure that the messages and values delivered are in line with the existing health messages. 


\section{CONCLUSION}

By using diffusion of innovation theory approach from Everett M. Rogers (2003), focusing on the role of opinion leaders, supported by multi-step flow theory and health communication concept, the results of this study show that to increase the effectiveness of health messages delivery towards millennials generation, Koalisi Indonesia Cegah Kanker Serviks (Indonesia Cervical Cancer Prevention Coalition) actively include celebrity opinion leaders participation in many activities, both online and offline, and one of the most interesting strategies used was an online clinic, which is considered quite effective as it makes it easier for people, especially millennials to get an education because they can see the counselling session wherever they are and whenever they want as long as they have an account. In addition, the public can also provide questions and comments directly on the Instagram live feature. Besides that, through new media, the ambassadors are also required to actively create engagement, either by replying to comments, DM, post activities related to the HPV vaccine, and so on. Furthermore, the use of new media is considered to be the most effective way because most millennials today feel afraid and ashamed to have an examination by a gynaecologist, so through this, they could get help and ask questions with much more ease. The selection of ambassadors by KICKS is also adjusted to existing community groups, and as for millennials, KICKS use Prilly Latuconsina and Syifa Hadju who are part of the millennial generation.

This study shows that what is done and said by opinion leaders regarding an innovation can be an important consideration for millennials. Besides that, the use of celebrities as opinion leaders by KICKS in introducing HPV vaccines can also help the process because there are similarities between them and millennials as members of the social system. However, it couldn't be denied that the use of celebrities as opinion leaders has its advantages and disadvantages, and interpersonal communication is still needed to support the diffusion of innovation. 


\section{ACKNOWLEDGEMENT}

The author would like to send the deepest gratitude and profound thanks to all the research informants, including Prilly Latuconsina as the ambassador of cervical cancer (Duta Kanker Serviks), Sondang Butar Butar as KICKS public relations, Novi Henriatika as KICKS public relations, Listyowati as KICKS members, Dr. Ardiansjah Dara Sjahruddin as obstetricians, Levina Masli \& Citra Pulandi Utomo as part of Indonesia millennials, for the support and help in writing this article.

\section{BIODATA}

Janette Maria Pinariya is a lecturer at Institute Communication \& Business LSPR. Responsible for managing communication methodology courses, supervising thesis, internship seminar, conducting research and community services. Email: janette.mp@lspr.edu

Andre Ikhsano is a lecturer at Institute Communication \& Business LSPR. Responsible for managing the Indonesian communication system, globalization and pop culture courses. Email: andre.i@lspr.edu

Aldila Maharani Sutjipto is a graduate at STIKOM The London School of Public Relations Jakarta, majoring in Public Relations. Her area of interest is communication, health and social issues. Email: aldilamaharani92@gmail.com 


\section{REFERENCES}

Anwar, S. L., Tampubolon, G., Van Hemelrijck, M., Hutajulu, S. H., Watkins, J., \& Wulaningsih, W. (2018). Determinants of cancer screening awareness and participation among Indonesian women. BMC Cancer, 18(1), 208.

Arya Dharma Shinta, Mohd. Azul Mohamad Salleh, \& Mohd. Nor Shahizan Ali. (2019). Analysis of the moderating effect of media literacy on cervical cancer preventive behaviours. Jurnal Komunikasi: Malaysian Journal of Communication, 35(1).

Ayuningtyas, D., \& Sutrisnawati, N. N. D. (2018). Indonesia's readiness to implement the HPV vaccine mandatory for school age. Health Science Journal of Indonesia, 9(2), 107-118.

Berkup, S. B. (2014). Working with generations $X$ and $Y$ in generation $Z$ period: Management of different generations in business life. Mediterranean Journal of Social Sciences, 5(19), 218-218.

Budiwati, M. (2012). Perancangan kampanye sosial cegah kanker serviks pada remaja melalui media desain komunikasi visual [Skripsi]. Retrieved from https://digilib.uns.ac.id/dokumen/detail/29783/Perancangan-Kampanye-SosialCegah-Kanker-Serviks-Pada-Remaja-Melalui-Media-Desain-Komunikasi-Visual

Butar, I. D. B. (2018). National culture and paternalistic leadership: Indonesian business context. Journal of Business and Entrepreneurship, 6(2), 58-62.

Centers for Disease Control and Prevention. (2016, 12 Februari). Vaccine information statement. Retrieved on 2018, October 18, from https://www.cdc.gov/vaccines/hcp/vis/vis-statements/hpv.html

Creswell, J. W., \& Poth, C. N. (2016). Qualitative inquiry and research design: Choosing among five approaches. Thousand Oaks: Sage publications.

Cram, P., Fendrick, A. M., Inadomi, J., Cowen, M. E., Carpenter, D., \& Vijan, S. (2003). The impact of a celebrity promotional campaign on the use of colon cancer screening: The Katie Couric effect. Archives of Internal Medicine, 163(13), 1601-1605.

Emma Mohamad, Abdul Latiff Ahmad, Sabariah Mohamed Salleh, \& Ummu Khadijah Wan Sulaiman. (2017). Breaking the traditional communication flow: Exploration of social media opinion leaders in health. SHS Web of Conferences, 33, p.00044.

Eng May Chuen, Edwin Michael, \& Teh Boon Teck. (2016). The role of media socialization agents in increasing obesity health literacy among Malaysian Youth. Jurnal Komunikasi: Malaysian Journal of Communication, 32(2). https://doi.org/10.17576/JKMJC-2016-3202-34

Erdogan, B. Z., Baker, M. J., \& Tagg, S. (2001). Selecting celebrity endorsers: The practitioner's perspective. Journal of Advertising Research, 41(3), 39-48.

Ghaddar, S. F., Valerio, M. A., Garcia, C. M., \& Hansen, L. (2012). Adolescent health literacy: the importance of credible sources for online health information. Journal of School Health, 82(1), 28-36.

Ghebreyesus, T. A., \& World Health Organisation. (2018). Cervical cancer: An NCD we can overcome. Geneva (Switzerland): World Health Organisation.

Global Cancer Observatory. (n.d.) Indonesia. Retrieved on 2019, October 28, from https://gco.iarc.fr/today/data/factsheets/populations/360-indonesia-fact-sheets.pdf

Han, B., Hedden, S. L., Lipari, R., Copello, E. A., \& Kroutil, L. A. (2015). Receipt of services for behavioural health problems: Results from the 2014 national survey on drug use and health. Rockville, MD: Substance Abuse and Mental Health Services Administration. 
Handayani, P., Yudoyono, H. S., Wardhany, I. I., \& Wimardhani, Y. S. (2017). Knowledge of Human Papilloma Virus among Female Dentists in Jakarta, Indonesia. Journal of International Dental and Medical Research, 10, 663-667.

Hoffman, S. J., \& Tan, C. (2015). Biological, psychological and social processes that explain celebrities' influence on patients' health-related behaviours. Archives of Public Health, 73(1), 3. http://dx.doi.org/10.1186/2049-3258-73-3

Hoffman, S. J., Mansoor, Y., Natt, N., Sritharan, L., Belluz, J., Caulfield, T., ... \& Sharma, A. M. (2017). Celebrities' impact on health-related knowledge, attitudes, behaviours, and status outcomes: Protocol for a systematic review, meta-analysis, and metaregression analysis. Systematic Reviews, 6(1), 13.

Katz, E., \& Lazarsfeld, P. F. (1966). Personal influence, the part played by people in the flow of mass communication. New Jersey, USA: Transaction Publishers.

Kau, A. K., \& Jung, K. (2004). Culture's consequences on consumer behaviour. Korea: KDI School of Public Policy and Management.

Kelly, J. A. (2004). Popular opinion leaders and HIV prevention peer education: Resolving discrepant findings, and implications for the development of effective community programmes. AIDS Care, 16(2), 139-150.

Koalisi Indonesia Cegah Kanker Serviks. (n.d). Tentang KICKS. Retrieved on 2018, August 20, from https://cegahkankerserviks.org/tentang-kicks

Kuswardani, I. (2012). Perilaku manusia dalam konsep Islam Jawa. Jawa Tengah, Indonesia: Universitas Muhammadiyah Surakarta.

Lazarsfeld, P., Berelson, B., \& Gaudet, H. (1944). The people's choice. How the voter makes up his mind in a presidential campaign. New York, NY: Columbia University Press.

Li, F., \& Du, T. C. (2011). Who is talking? An ontology-based opinion leader identification framework for word-of-mouth marketing in online social blogs. Decision Support Systems, 51(1), 190-197.

Nurhasanah, N., \& Afiyanti, Y. (2017). Factors affecting behaviours of cervical cancer screening using VIA (Visual Inspection with Acetic Acid) method on women in Srengseng Sawah Jakarta Indonesia. UI Proceedings on Health and Medicine, 2.

Ognyanova, K. (2017). Multistep flow of communication: Network effects. The International Encyclopedia of Media Effects, 1-10.

Onuki, M., Matsumoto, K., Iwata, T., Yamamoto, K., Aoki, Y., Maenohara, S., ... \& Tasaka, N. (2020). Human papillomavirus genotype contribution to cervical cancer and precancer: Implications for screening and vaccination in Japan. Cancer science, 111(7), 2546-2557. https://doi.org/10.1111/cas.14445

Parrott, R. (2009). Talking about health: Why communication matters (Vol. 7). West Sussex, UK: John Wiley \& Sons.

Rahmadiana, M. (2012). Komunikasi kesehatan: Sebuah tinjauan. Jurnal Psikogenesis, 1(1), 88-94.

Rizal, F. (2012). Penerapan teori difusi inovasi dalam perubahan sosial budaya. Hikmah, VI(1), 129-140.

Rifeni. (2019, March 8). Sejak jadi duta, Prilly Latuconsina serukan cegah kanker serviks. Retrieved on 2019, October 27, from https://www.pantau.com/berita/sejak-jadiduta-prilly-latuconsina-serukan-cegah-kanker-serviks

Rogers, M. E. (2003). Diffusion of innovations. Newyork City, NY: The Free Press.

Schiavo, R. (2013). Health communication: From theory to practice (Vol. 217). West Sussex, UK: John Wiley \& Sons. 
Selden, C. R., Zorn, M., Ratzan, S., \& Parker, R. M. (2000, February). Health literacy. Retrieved on 2019, August 19, from https://www.researchgate.net/publication/230877250_National_Library_of_Medici ne_Current_Bibliographies_in_Medicine_Health_Literacy

Setiawan, D., Dolk, F. C., Suwantika, A. A., Westra, T. A., WIlschut, J. C., \& Postma, M. J. (2016). Cost-utility analysis of human papillomavirus vaccination and cervical screening on cervical cancer patient in Indonesia. Value in Health Regional Issues, 9, 84-92.

Spagnoletti, B. R. M., Bennett, L. R., Wahdi, A. E., Wilopo, S. A., \& Keenan, C. A. (2019). A qualitative study of parental knowledge and perceptions of human papillomavirus and cervical cancer prevention in rural central Java, Indonesia: Understanding community readiness for prevention interventions. Asian Pacific Journal of Cancer Prevention (APJCP), 20(8), 2429.

Stansberry, K. (2012). One-step, two-step, or multi-step flow: The role of influencers in information processing and dissemination in online, interest-based publics (Dissertation PhD, University of Oregon, OR). Retrieved from http://hdl.handle.net/1794/12416

Sukmawati, E. (2018). Pengaruh pendidikan kesehatan tentang kanker servik terhadap peningkatan motivasi untuk mencegah kanker servik. Global Health Science (GHS), 3(1), 7-11.

Sutjipto, A. M., \& Pinariya, J. M. (2019). Pengenalan vaksinasi hpv oleh koalisi Indonesia cegah kanker serviks dengan pendekatan teori difusi inovasi. WACANA: Jurnal IImiah IImu Komunikasi, 18(2). https://doi.org/10.32509/wacana.v18i2.910

Titisari, I., \& Setyarini, A. I. (2017). Factor affecting precancerous lesions of cervical cancer incidence in kediri Indonesia. International Journal of Innovative Science and Research Technology, 2(7).

Valente, T. W., \& Pumpuang, P. (2006). Identifying Opinion Leaders to Promote Behavior Change. Health Education \& Behavior, 34(6), 881-896. https://doi.org/10.1177/1090198106297855

Weimann, G. (2017). Multistep flow of communication: Evolution of the paradigm. The International Encyclopedia of Media Effects, 1-10. https://doi.org/10.1002/9781118783764.wbieme0055

Yoo, W. (2015). The influence of celebrity exemplars on college students' smoking. Journal of American College Health, 64(1), 48-60. 